ОЦІНКА БАЗОВИХ УМІНЬ І НАВИЧОК, ВМОТИВОВАНОСТІ ТА ДУМКИ ПЕДАГОГІЧНИХ ПРАЦІВНИКІВ У СФЕРІ МЕДИЧНОЇ ОСВІТИ ЩОДО ЗАПРОВАДЖЕННЯ НОВІТНІХ ТЕХНОЛОГІЙ ДИСТАНЦІЙНОГО ФОРМАТУ НАВЧАННЯ У ПОВСЯКДЕННУ ПЕДАГОГІЧНУ РОБОТУ

\title{
THE ESTIMATION OF BASELINE SKILLS, MOTIVATION, AND THOUGHTS MEDICAL EDUCATORS FOR THE INTRODUCTION OF NEW DISTANCE LEARNING TECHNOLOGIES IN EVERYDAY PEDAGOGICAL WORK
}

Стаття присвячена важливості та необхідності оцінки базових умінь і навичок, вмотивованості та думки педагогічних працівників у сорері медичної освіти щодо запровадження новітніх технологій дистанційного фрормату навчання у повсякденну педагогічну роботу перед початком тренінгу підвищення кваліфікації викладачів закладу вищої медичної освіти. Обговорено необхідність проведення курсів підвищення квалісрікаціі викладачів закладів медичної освіти з використання новітніх інформаційно-освітніх технологій, зокрема платорорми дистанчійного навчання, базуючись на загальнодержавній стратегії розвитку медичної освіти та потреби у безперервному фраховому розвитку медичних працівників. Проведення базової оцінки ставлення, вмотивованості, базових навичок дає інформацію щодо ефективної побудови тренінгу у конкретному навчальному середовищі, виокремлення цілей і задач. Проведення опитування перед початком тренінгів є важливою складовою частиною педагогічного дизайну. Саме від базової оцінки залежить побудова навчальної траєкторії під конкретну цільову групу тих, хто навчається. Базова оцінка $є$ важливою для порівняння й оцінки досягнутих результатів. Основна увага зосереджується на результатах анкетування викладачів перед початком електронного навчального курсу, який розроблювався для підвищення кваліфрікації викладачів закладів вищої медичної освіти. Результати анкетування було покладено у створення навчальної програми електронного навчального курсу «Основи методології розробки електронних курсів у сорері медичної освіти». Проведення базовоі оцінки базових умінь і навичок, вмотивованості $є$ важливим етапом планування та проведення тренінгів, а також запорукою їх успішності. Навчальні тренінги відповідно до сучасних моделей оцінки ефективності навчання, зокрема моделі оцінки ефективності навчання Дональда Кирпатрика, зміна ставлення, набуття умінь $і$ навичок, які впливають на повсякденну працю й отримання результатів, є ефективними.

Ключові слова: опитування, анкетування, педагогічний дизайн, вмотивованість, модель оцінки навчання Дональда Кирпатрика, дистанційне навчання, медична освіma.

The article is devoted to the importance and necessity of assessing the basic skills, motivation, and opinion of the medical educators on the introduction of new distance learning technologies in everyday pedagogical work before the training of teachers of higher medical education. The necessity for advanced training courses for teachers of medical education institutions on the use of the information and educational technologies, including distance learning platform, based on the national strategy for the development of medical education and the necessity for the continuous professional development of health workers. Conducting a basic assessment of attitudes, motivation, basic skills provides information on the effective construction of training in a particular learning environment, highlighting goals and objectives. Surveying the start of training is an important component of pedagogical design. It is the basic assessment that determines the construction of the correct learning trajectory for a specific target group of learners. Baseline evaluation is important for comparing and evaluating the results achieved. The main focus is on the results of the survey of teachers before the start of the e-learning course, which was developed to improve the skills of teachers of higher medical education. The results of the questionnaire were used to create a curriculum for e-learning course "Fundamentals of methodology of the electronic courses development in the field of medical education" for improving the qualification of medical education institutions. Carrying out a basic assessment of basic skills and motivations is an important stage of planning and conducting training, as well as a guarantee of their success. Training following modern models of evaluation of learning effectiveness, in particular, the model of evaluation of learning effectiveness of Donald Kirkpatrick, change of attitude, acquisition of skills, and abilities that affect daily work and obtaining results are effective.

Key words: survey, questionnaire, pedagogical design, motivation, Donald Kirpatrick's learning assessment model, distance learning, medical education.
Харківського національного медичного університету
Постановка проблеми у загальному вигляді. Проведення якісних тренінгів підвищення кваліфікації викладачів закладів медичної освіти з огляду на загальнодержавну стратегію безперервного фрахового розвитку медичних працівників стає дуже актуальною вимогою сучасності та збереження конкурентоспроможності закладів освіти, яким із часом необхідно буде конкурувати не тільки між собою, а й із комерційними проектами та про- ектами, що супроводжують фрармацевтичні компанії у сорері медичної освіти. Розроблення програм підвищення кваліфрікації, які б відповідали потребам і вимогам сучасності, збереже престижність, значущість традиційних фоорм освіти. Програми навчання викладачів закладів медичної освіти на загальнодержавному рівні відсутні та частково реалізуються при проходженні магістратури з педагогіки вищої школи медичними педагогами. 
Особливо актуальним $є$ проведення онлайн-тренінгів підвищення кваліфікації викладачів закладів вищої медичної освіти та розробка комплексних електронних курсів, що дозволить реалізувати викладачам ефективний супровід додипломного та післядипломного етапів медичної освіти.

Аналіз останніх досліджень і публікацій. Протягом останніх років вітчизняні автори у своїх публікаціях наголошують на необхідності впровадження інноваційних інорормаційно-освітніх вебтехнологій у медичну освіту $[1$, с. $3 ; 17$, с. 477 ; 15, с. 67], обґрунтовувалася необхідність впровадження SMART-технологій у модернізацію післядипломної освіти [3, с. 236], що б відповідало реалізації Європейських стандартів вищої освіти [12, с. 55]. Досвід використання та впровадження інфрормаційно-освітніх веб-технологій для забезпечення медичної освіти широко обговорювався в авторських публікаціях попередніх років [4, с. 87; 5 , с. $531 ; 6$, с. $225 ; 7$, с. 226 ; 8 , с. $1-36$; 9 , с. 68 ; 10 , с. $63 ; 11$, с. $1-84 ; 19$, с. $10 ; 20$, с. 43$]$.

Проаналізовано досвід вітчизняних медичних освітніх закладів щодо проведення підготовки, перепідготовки медичних педагогів. О. Фурик, І. Юрченко аналізували роль тьютора у проблемноорієнтованому навчанні в галузі медичної освіти, підкреслюючи зміну ролі викладача за сучасних умов із переважанням його координаторської функції [18, с. 166]. С. Напалков у своїй публікації наголошує на необхідності технологічного оновлення підготовки сучасного педагога [13, с. 833]. М. Рожко та співатори характеризували діяльність навчально-тренінгового центру для викладачів із метою підвищення профресійної, мовної компетентності та володіння сучасними інноваційними технологіями навчання [14, с. 65]. Ю. Вороненко та співавтори ссрормулювали напрями, за якими слід проводити розвиток викладачів вищої медичної школи, та вони не відображують необхідність підвищення професійної компетентності викладачів у сорері інформаційно-освітніх технологій [2, с. 10]. У попередніх авторських публікаціях розглядалася програма підвищення кваліфрікації педагогів закладів вищої медичної освіти 3 використання інорормаційно-освітніх веб-технологій у медичній освіті [10, с. 60-67], яка і слугувала підґрунтям для розробки програми пілотного дистанційного курсу підвищення кваліфрікації викладачів закладів медичної освіти «Основи методології розробки електронних курсів в сорері медичної освіти». У своїй публікації І. Соколова охарактеризувала професійний розвиток викладачів медичного університету: досвід використання навчальної платформи MoodleCloud [16, с. 29-37].

Виділення не вирішених раніше частин загальної проблеми. У попередніх публікаціях не обговорювалася стратегія побудови програми онлайн-тренінгів підвищення кваліфікації викла- дачів закладів вищої медичної освіти з урахуванням попередньої оцінки базових умінь і навичок, вмотивованості та думки педагогічних працівників у сорері медичної освіти щодо запровадження новітніх технологій дистанційного фрормату навчання у повсякденну педагогічну роботу. Розробка адаптивних тренінгів підвищення кваліфікації викладачів у сфрері медичної освіти може підвищити як якість підготовки майбутніх фрахівців, так і якість надання медичної допомоги.

Мета статті - продемонструвати досвід стратегії побудови програми онлайн-тренінгу підвищення кваліфікації викладачів закладу вищої медичної освіти з урахуванням попередньої оцінки базових умінь і навичок, вмотивованості та думки педагогічнихпрацівників усорері медичної освіти щодозапровадження новітніх технологій дистанційного формату навчання у повсякденну педагогічну роботу.

Виклад основного матеріалу. Створення ефективних навчальних матеріалів, у т. ч. розроблених із використанням інорормаційних технологій, може бути реалізовано відповідно до концепцій і моделей педагогічного дизайну. Педагогічний дизайн - це наукова дисципліна, яка займається розробкою найбільш ефективних, раціональних і комсрортних способів, методів і систем навчання, які можуть бути використані у сорері професійної педагогічної практики. Відповідно до найбільш поширеної моделі педдизайну ADDIE (Analysis, Design, Development, Implementation, Evaluation (1975)) виділяють такі етапи розробки навчальних матеріалів: аналіз, проектування, розробку, реалізацію, оцінку, завдяки якій можуть бути прийняті рішення щодо удосконалення розроблених навчальних матеріалів. Стадія аналізу є найважливішою стадією розробки навчальних матеріалів. Саме під час цього етапу виділяються ключові елементи, вивчаються потреби тих, хто навчається, і завдання викладача, формулюються вимірні та зрозумілі цілі навчання, оцінюється цільова аудиторія і фрорми роботи з нею, а також складається список очікуваних результатів. Для підвищення ефективності ця стадія також розбивається на кілька етапів, що дозволяють за рахунок поступового виявлення ключових точок чітко сфрормулювати завдання. Ретельно опрацьовані цілі допомагають визначити інструментарій навчального курсу, ступінь його наповнення інтерактивними елементами та застосовність вже наявних матеріалів і методик. Тут вже можна чітко визначити методики оцінки ефективності самого процесу навчання. Після того, як виконано аналіз, цілі навчання можна уточнити, що дасть можливість почати розробку власне навчальних матеріалів.

Курс «Основи методології розробки електронних курсів» було створено для викладачів Харківського національного медичного університету 3 метою опанування ними навичок розробки 
Перелік запитань анкетування викладачів ХНМУ перед початком навчального курсу «Основи методології розробки електронних курсів у сфері медичної освіти»

\begin{tabular}{|c|c|}
\hline 1. Ваш вік. & $\begin{array}{l}\text { - До } 30 \text { років } \\
\text { - 30-40 років } \\
\text { - 40-50 років } \\
\text { - Більше } 50 \text { років }\end{array}$ \\
\hline 2. Який у Вас стаж педагогічної роботи? & $\begin{array}{l}\text { - До } 5 \text { років } \\
\text { - 5-10 років } \\
\text { - 10-20 років } \\
\text { - Більше } 20 \text { років } \\
\end{array}$ \\
\hline 3. Чи маєте Ви ступінь магістра з педагогіки? & $\begin{array}{l}\text { - Так } \\
\text { - Ні } \\
\text { - Зараз проходжу навчання }\end{array}$ \\
\hline $\begin{array}{l}\text { 4. Як часто у своїй педагогічній діяльності Ви вико- } \\
\text { ристовуєте які-небудь інорормаційно-освітні веб- } \\
\text { технології? }\end{array}$ & $\begin{array}{l}\text { - Ніколи не використовую } \\
\text { - Щодня } \\
\text { - Кілька разів на тиждень } \\
\text { - Кілька разів на місяць }\end{array}$ \\
\hline $\begin{array}{l}\text { 5. Чи був у Вас досвід роботи на будь-якій плат- } \\
\text { формі дистанційного навчання (як студента)? }\end{array}$ & $\begin{array}{l}-\mathrm{Tak} \\
-\mathrm{Hi}\end{array}$ \\
\hline $\begin{array}{l}\text { 6. Чи був у Вас досвід роботи на будь-якій плат- } \\
\text { фрормі дистанційного навчання (як викладача)? }\end{array}$ & $\begin{array}{l}-\mathrm{Tak} \\
-\mathrm{Hi}\end{array}$ \\
\hline $\begin{array}{l}\text { 7. Як би Ви оцінили свої навички роботи в } \\
\text { PowerPoint для підготовки презентацій? }\end{array}$ & $\begin{array}{l}\text { - Просунутий користувач } \\
\text { - Середній рівень } \\
\text { - Недостатній рівень } \\
\text { - Не використовую в роботі }\end{array}$ \\
\hline $\begin{array}{l}\text { 8. Чи вмієте Ви створювати анімацію для пояснення } \\
\text { теоретичного матеріалу по Вашому предмету? }\end{array}$ & $\begin{array}{l}\text { - Вмію створювати просту анімацію } \\
\text { - Вмію створювати складну анімацію } \\
\text { - Не використовую в роботі } \\
\end{array}$ \\
\hline $\begin{array}{l}\text { 9. Як часто Ви проводите опитування учнів за допо- } \\
\text { могою автоматизованого тестування? }\end{array}$ & $\begin{array}{l}\text { - Ніколи не використовую } \\
\text { - Щодня } \\
\text { - Кілька разів на тиждень } \\
\text { - Кілька разів на місяць } \\
\end{array}$ \\
\hline $\begin{array}{l}\text { 10. Чи проводили Ви коли-небудь вебінари / або } \\
\text { були доповідачем на телеконференції? }\end{array}$ & $\begin{array}{l}-\mathrm{Tak} \\
-\mathrm{Hi}\end{array}$ \\
\hline $\begin{array}{l}\text { 11. Як часто Ви берете участь як слухач у вебіна- } \\
\text { pax? }\end{array}$ & $\begin{array}{l}\text { - Ніколи не беру участь } \\
\text { - Щодня } \\
\text { - Кілька разів на тиждень } \\
\text { - Кілька разів на місяць } \\
\end{array}$ \\
\hline $\begin{array}{l}\text { 12. Чи проходили Ви коли-небудь тренінги підви- } \\
\text { щення кваліфрікації, що стосуються дистанційного } \\
\text { навчання? }\end{array}$ & $\begin{array}{l}-\mathrm{Tak} \\
-\mathrm{Hi}\end{array}$ \\
\hline $\begin{array}{l}\text { 13. Чи проводили Ви коли-небудь звукозапис своїх } \\
\text { доповідей, презентацій? }\end{array}$ & $\begin{array}{l}-\mathrm{Tak} \\
-\mathrm{Hi} \\
\end{array}$ \\
\hline $\begin{array}{l}\text { 14. Чи проводили Ви коли-небудь відеозапис своїх } \\
\text { доповідей, презентацій? }\end{array}$ & $\begin{array}{l}-\mathrm{Tak} \\
-\mathrm{Hi}\end{array}$ \\
\hline $\begin{array}{l}\text { 15. Як би Ви оцінили свою зацікавленість у впрова- } \\
\text { дженні інформаційно-освітніх технологій у навчаль- } \\
\text { ний процес (5 - максимальна зацікавленість, } \\
4 \text { - середня зацікавленість, } 3 \text { - нейтральна зацікав- } \\
\text { леність, } 2 \text { - мінімальна зацікавленість, } 1 \text { - зацікав- } \\
\text { леність відсутня) }\end{array}$ & $\begin{array}{l}-1 \\
-2 \\
-3 \\
-4 \\
-5\end{array}$ \\
\hline $\begin{array}{l}\text { 16. Як би Ви оцінили зацікавленість Ваших студен- } \\
\text { тів лекціями за шкалою від } 1 \text { до } 5 \text { (5 - максимальна } \\
\text { зацікавленість, } 4 \text { - середня зацікавленість, } 3 \text { - ней- } \\
\text { тральна зацікавленість, } 2 \text { - мінімальна зацікавле- } \\
\text { ність, } 1 \text { - зацікавленість відсутня) }\end{array}$ & $\begin{array}{l}-1 \\
-2 \\
-3 \\
-4 \\
-5\end{array}$ \\
\hline $\begin{array}{l}\text { 17. Як би Ви оцінили зацікавленість Ваших студен- } \\
\text { тів на практичних заняттях за шкалою від } 1 \text { до } 5 \text { (5 - } \\
\text { максимальна зацікавленість, } 4 \text { - середня зацікавле- } \\
\text { ність, } 3 \text { - нейтральна зацікавленість, } 2 \text { - мінімальна } \\
\text { зацікавленість, } 1 \text { - зацікавленість відсутня) }\end{array}$ & $\begin{array}{l}-1 \\
-2 \\
-3 \\
-4 \\
-5\end{array}$ \\
\hline
\end{tabular}


Продовження таблиці 1

\begin{tabular}{|c|c|}
\hline $\begin{array}{l}\text { 18. Які на Ваш погляд переваги при впровадженні } \\
\text { в освітній процес веб-технологій? }\end{array}$ & $\begin{array}{l}\text { Підвищення якості освіти } \\
\text { Особистісно-орієнтований підхід у навчанні } \\
\text { Доступність знань } \\
\text { Висока технологічність представленого матеріалу: аудіо-, } \\
\text { відеоматеріали, сучасні рекомендації з діагностики та } \\
\text { лікування } \\
\text { Без відриву від основної діяльності в асинхронному режимі } \\
\text { Адаптивність (відображення всіх сучасних тенденцій } \\
\text { освіти та інфрормаційного суспільства) } \\
\text { Об'єктивізація й автоматична система оцінювання знань } \\
\text { студентів } \\
\text { Координування навчального процесу }\end{array}$ \\
\hline $\begin{array}{l}\text { 19. Які, на Ваш погляд, недоліки має впровадження } \\
\text { інфрормаційно-освітніх веб-технологій? }\end{array}$ & $\begin{array}{l}\text { - Не бачу недоліків } \\
\text { - Необхідність постійного підвищення кваліфікації } \\
\text { - Необхідність освоєння сучасних освітніх технологій } \\
\text { - Значні часові витрати на підготовку якісного освітнього } \\
\text { контенту } \\
\text { - Необхідність залучення великої кількості персоналу } \\
\text { - Є недоліки, проте вони переборні за правильної орга- } \\
\text { нізації навчально-педагогічної діяльності та більшого } \\
\text { залучення студентів }\end{array}$ \\
\hline $\begin{array}{l}\text { 20. Як часто Ви читаєте педагогічну літературу, при- } \\
\text { свячену сучасним педагогічним технологіям? }\end{array}$ & $\begin{array}{l}\text { - Ніколи не читаю } \\
\text { - Щодня } \\
\text { - Кілька разів на тиждень } \\
\text { - Кілька разів на місяць } \\
\end{array}$ \\
\hline $\begin{array}{l}\text { 21. Чи готові Ви витрачати час на навчання себе і } \\
\text { підвищення своєї кваліфрікації відповідно до нових } \\
\text { тенденцій в освіті? }\end{array}$ & $\begin{array}{l}\text { - Не маю часу на підвищення квалісрікації } \\
\text { - Можу щодня приділяти цьому час } \\
\text { - Можу кілька разів на тиждень приділяти цьому час } \\
\text { - Можу кілька разів на місяць приділяти цьому час }\end{array}$ \\
\hline \multicolumn{2}{|l|}{$\begin{array}{l}\text { 22. що Ви чекаєте від навчального курсу, який стар- } \\
\text { тував, що б Ви хотіли почути, чому навчитися? }\end{array}$} \\
\hline \multicolumn{2}{|l|}{$\begin{array}{l}\text { 23. Що б Ви не хотіли почути в рамках навчального } \\
\text { курсу? }\end{array}$} \\
\hline $\begin{array}{l}\text { 24. Які мотиваційні складники можуть бути визна- } \\
\text { чальними для Вас у впровадженні інфоормаційно- } \\
\text { освітніх технологій у рутинну педагогічну практику? }\end{array}$ & $\begin{array}{l}\text { - Підвищення есрективності в роботі } \\
\text { - Полегшення повсякденних завдань } \\
\text { - Професійний розвиток }\end{array}$ \\
\hline
\end{tabular}

електронних курсів на платформі дистанційного навчання ХHМУ для забезпечення дистанційної освіти та змішаного навчання. Мета курсу полягала у вивченні основ методології розробки електронних курсів у сорері медичної освіти, вивченні основних принципів сучасної дистанційної освіти, основ створення якісного навчального контенту, опанування практичними навичками роботи на платорормі дистанційного навчання для забезпечення додипломного та післядипломного етапів навчання. Велика увага була приділена саме навичкам розробки електронних курсів у сорері медичної освіти та практичним результатам курсу. 3 урахуванням базових принципів педагогічного дизайну, а також відповідно до сучасних моделей оцінки есрективності навчання, зокрема моделі оцінки еорективності навчання Дональда Кирпатрика, перед початком тренінгу підвищення кваліфікації викладачам було запропоновано дати відповіді на анонімне опитування із питаннями одиночного, множинного вибору та відкритими питаннями (табл. 1). Анкетування проводилося анонімно з метою оцінки базового рівня навичок, аналізу побажань викладачів щодо навчального електро- нного курсу, а також оцінки ставлення викладачів до того, чи іншого аспекту впровадження інформаційно-освітніх технологій у навчальний процес. В опитуванні викладачів взяли участь 234 науково-педагогічні працівники ХНМУ.

Надалі результати анонімного опитування було використано для підготовки програми підвищення кваліфікації викладачів з урахуванням наданих відповідей і первинного плану тематичного наповнення електронного навчального курсу. 3 урахуванням опитування було сорормовано 20 тем електронного навчального курсу.

При аналізі вікового складу слухачів курсу виявлено, що до 30 років було 28 респондентів $(11,97 \%), 30-40$ років - 92 (39,32\%), 40-50 років 65 (27,78\%), більше 50 років - 49 (20,94\%) (рис. 1).

Також аналізувався стаж педагогічної роботи слухачів курсів підвищення кваліфрікації. Виявлено, що стаж до 5 років мав 61 викладач (26,07\%), 5-10 років - 60 (25,64\%), 10-20 років - 60 (25,64\%), більше ніж 20 років - 53 (22,65\%) (рис. 2).

Більшість викладачів, залучених до курсу підвищення кваліфрікації в електронному навчальному курсі, мали ступінь магістра педагогіки - 117 викла- 


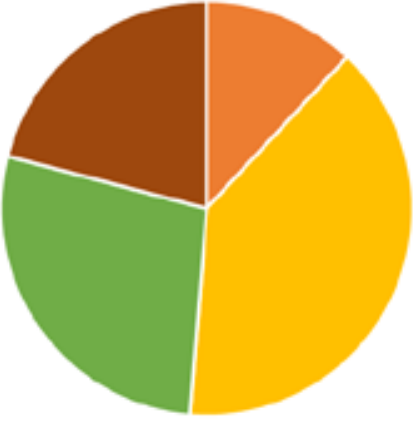

= до 30 років $=30-40$ років $=40-50$ років $=6$ більше 50 років

Рис. 1. Вік слухачів пілотного дистанційного курсу «Основи методології розробки електронних курсів у сорері медичної освіти»

дачів (50,00\%), 103 не мали ступеня магістра з педагогіки (44,02\%), а 14 респондентів проходили навчання (5,98\%) (рис. 3).

До проходження навчання в електронному навчальному курсі 22 респонденти у своїй педагогічній діяльності не використовували інформаційно-освітні веб-технології (9,40\%), 85 респондентів використовували щодня (36,32\%), 90 - кілька разів на тиждень $(38,46 \%)$, а 37 - кілька разів на місяць (15,81\%) (рис. 4).

У більшості викладачів не було попереднього досвіду роботи на будь-якій платорормі дистанційного навчання як студента - 140 викладачів (59,83\%), і 94 викладача мали попередній досвід проходження електронних навчальних курсів на платорормах дистанційного навчання (40,17\%) (рис. 5).

У більшості викладачів не було попереднього досвіду роботи на будь-якій платорормі дистанційного навчання як викладача - 193 респонденти (82,48\%), і 41 викладач (17,52\%) мав попередній

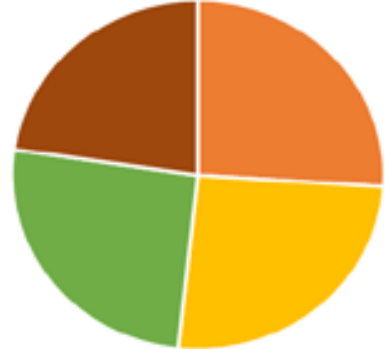

$$
\begin{array}{ll}
=\text { до } 5 \text { років } & \text { " 5-10 років } \\
=10-20 \text { років } & \text { " більше ніж } 20 \text { років }
\end{array}
$$

Рис. 2. Педагогічний стаж слухачів пілотного дистанційного курсу «Основи методології розробки електронних курсів у сфрері медичної освіти»

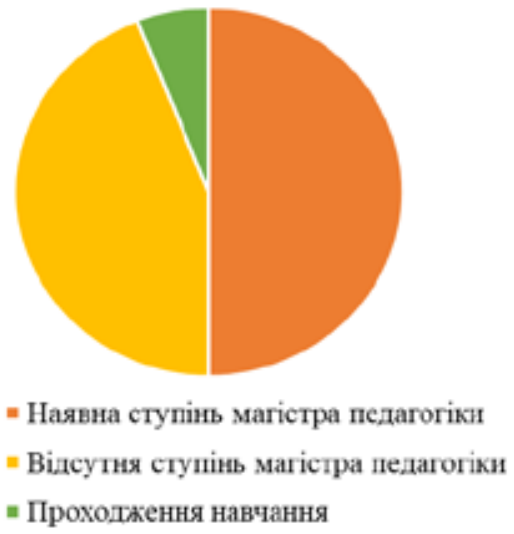

Рис. 3. Наявність ступеня магістра з педагогіки у слухачів курсу

досвід викладання на платформах дистанційного навчання (рис. 6).

Свої навички роботи у PowerPoint для підготовки презентацій як просунутий користувач оцінили 65 респондентів $(27,78 \%)$, як середній

пару раз на місяць

пару раз на тиждень

використовували щодня

не використовували інформаційноосвітні веб-технології у педагогічній роботі

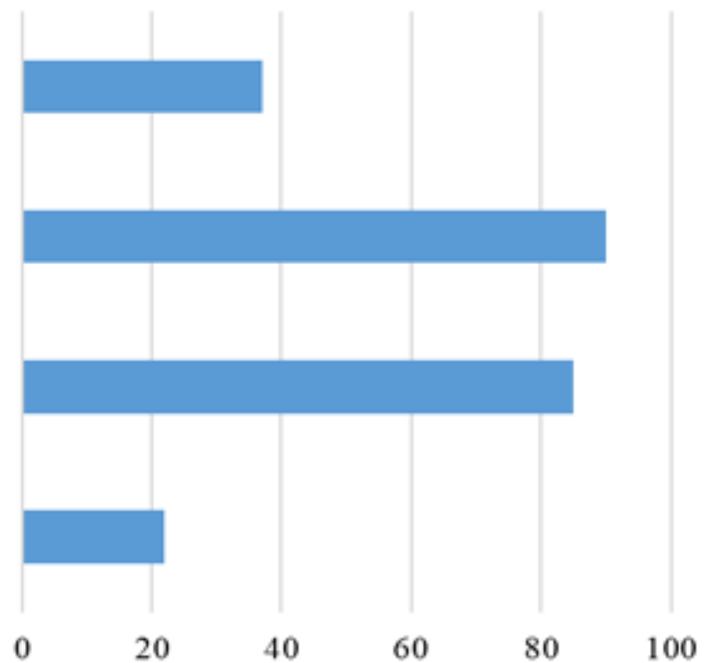

Рис. 4. Використання веб-технологій у педагогічній діяльності слухачами курсу до початку пілотного дистанційного курсу «Основи методології розробки електронних навчальних курсів у сорері медичної освіти» 


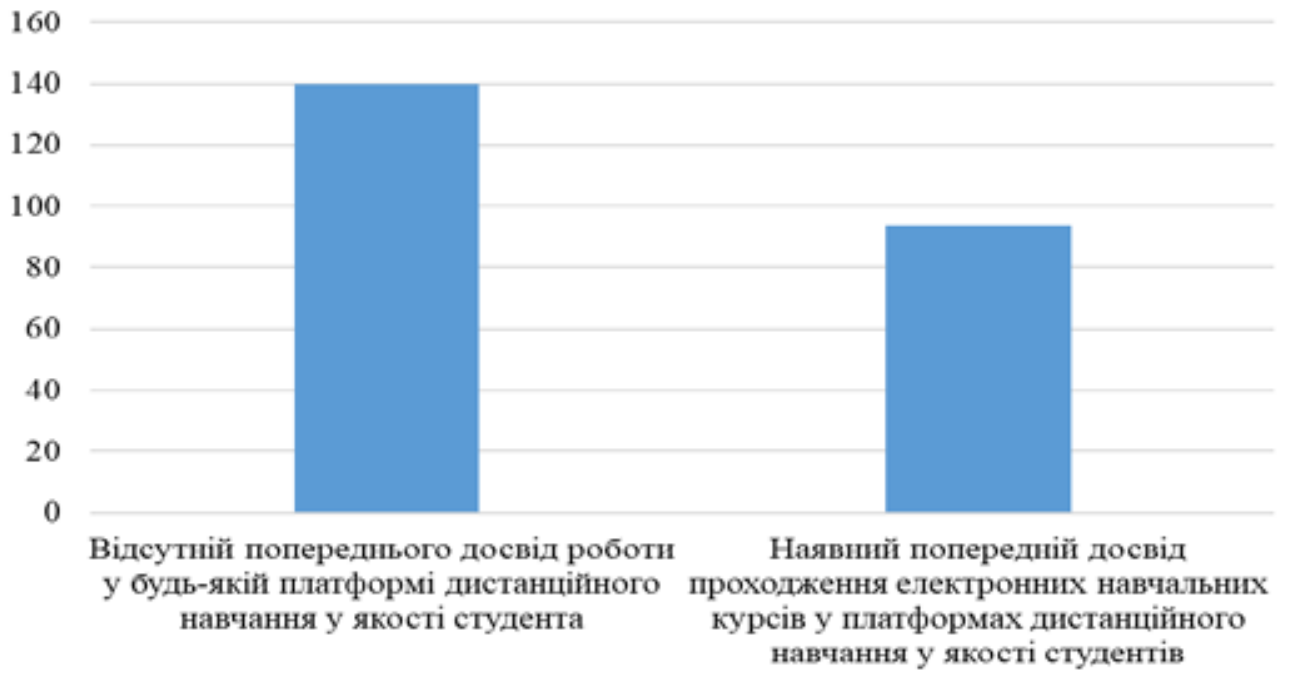

Рис. 5. Попередній досвід роботи на будь-якій платформі дистанційного навчання як студента

Наявний попередній досвід проходження електронних навчальних курсів у платформах дистанційного навчання у якості викладача

Відсутній попереднього досвід роботи у будь-якій платформі дистанщійного навчання у якості викладача

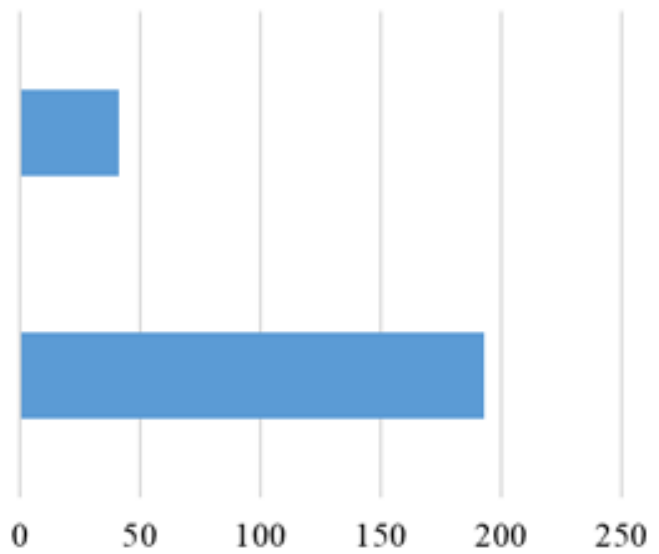

Рис. 6. Попередній досвід роботи на будь-якій платформі дистанційного навчання як викладача

Не використовуюу свойй роботі

Навички роботи у PowerPoint для підготовки презентацій як недостатній рівень

Навички роботи у PowerPoint для підготовки презентацій як середній рівень

Навички роботи у PowerPoint для підготовки презентацій як просунутий користувач

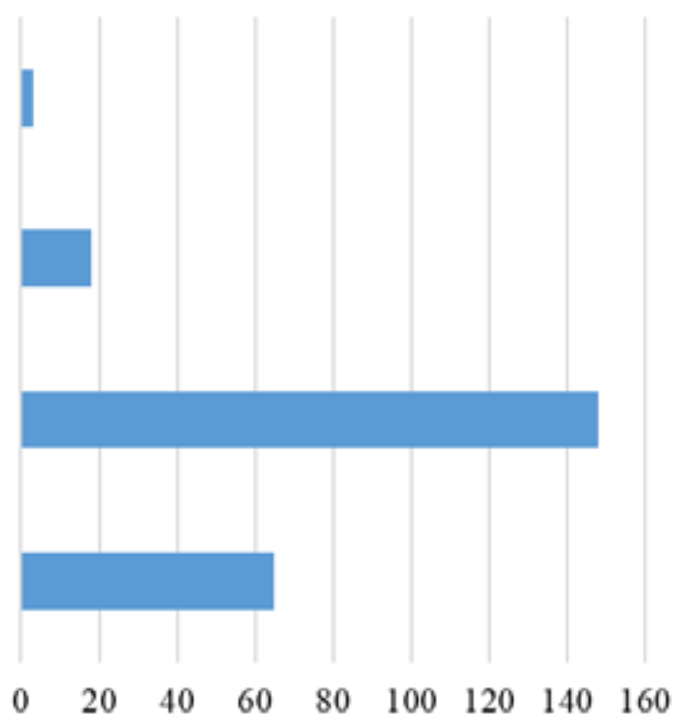

Рис. 7. Оцінка навичок роботи у PowerPoint 
Не внкористувую у педагогітій poботі

Вміння створювати складну анімацію

Вміння створювапи просту аніманію

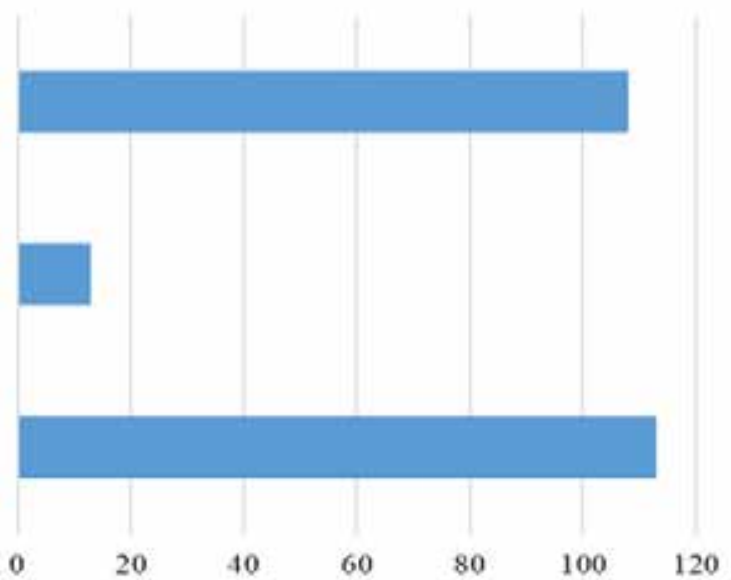

Рис. 8. Оцінка вміння створювати анімацію для пояснення теоретичного матеріалу до початку навчання на пілотному дистанційному курсі «Основи методології розробки електронних курсів у сорері медичної освіти»

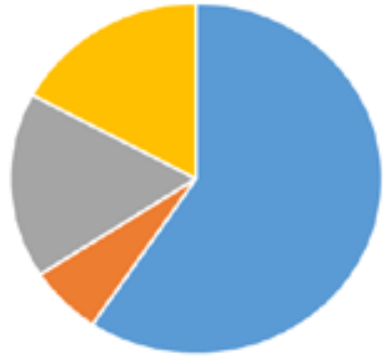

= Ніколи не створюенти і не проподити автоматияонапе тестування

" Використовують автоматизоване тестування подня

" Впкористовують автоматноване тестувания пару раз на пшждеш

= Використонують автоматизонане тестунания пару раз в місяпь

Рис. 9. Оцінка проведення автоматизованого тестування до початку навчання на пілотному дистанційному курсі «Основи методології розробки електронних курсів у сорері медичної освіти»

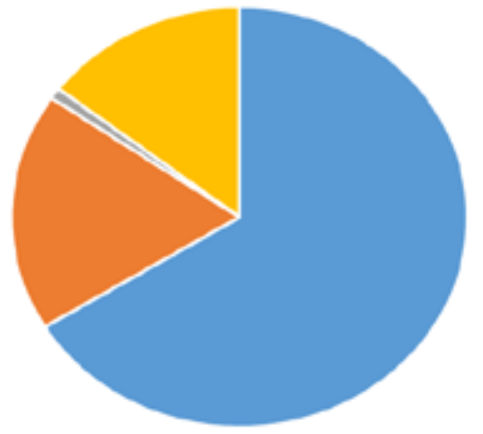

- Участь у якості слухача у вебінарах пару разів на місяш

= Ніколи не брали участі в вебінарах у якості слухача

= Приймають участь у вебінарах у якості слухача шодня

= Участь у якості слухача у вебінарах пару разів на тиждень

Рис. 11. Досвід участі у вебінарах як слухача до початку навчання на пілотному дистанційному курсі «Основи методології розробки електронних курсів у сорері медичної освіти»

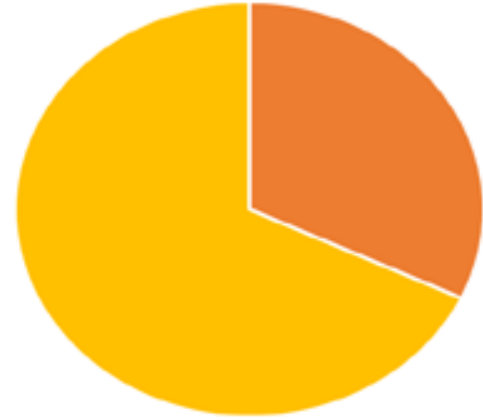

= Досвід проведення вебінарів у якості спікеру

= Досвід проведення вебінарів у якості спікеру відсутній

Рис. 10. Попередній досвід проведення вебінарів як доповідача до початку навчання на пілотному дистанційному курсі «Основи методології розробки електронних курсів у сфері медичної освіти»

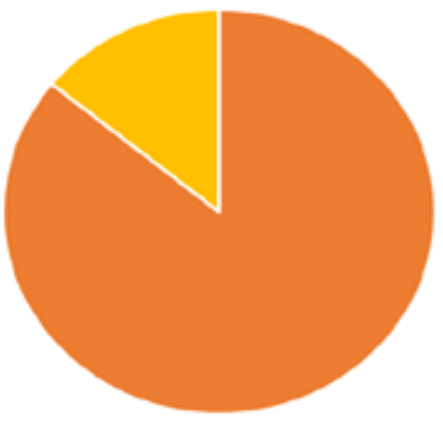

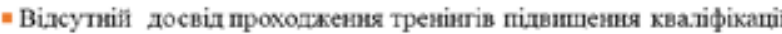
стосовно дистантійного научания

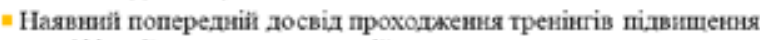
кватіфікапї стосовно дистаншійного научания

Рис. 12. Досвід проходження тренінгів підвищення кваліфікації по дистанційному навчанню до початку навчання на пілотному дистанційному курсі «Основи методології розробки електронних курсів у сорері медичної освіти» 
Наявний попередній досвід проведення відеозапису своїх доповідей, презентацій

Відсутній попередній досвід проведення відеозапису своїх доповідей, презентацій

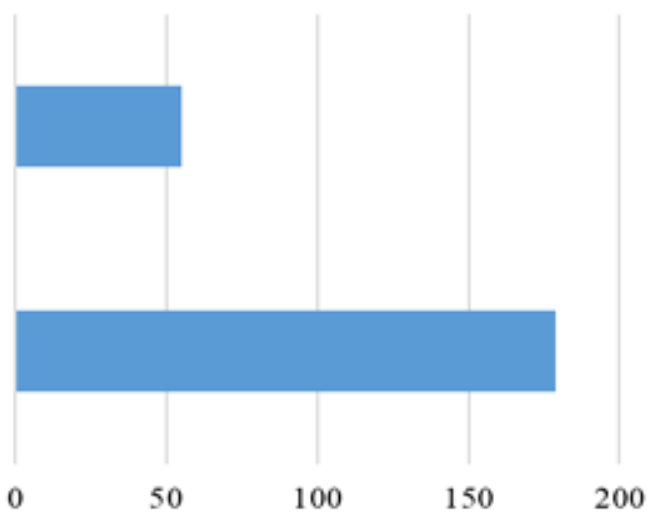

Рис. 13. Досвід проведення звукозапису доповідей, презентацій до початку навчання на пілотному дистанційному курсі «Основи методології розробки електронних курсів у сорері медичної освіти»

Наявини попереднің досвід проведешия звукозатису своїх доповілей, презентаній

Відсутній попередній досвід проведення звукозапису своіх доповідеї, презентації

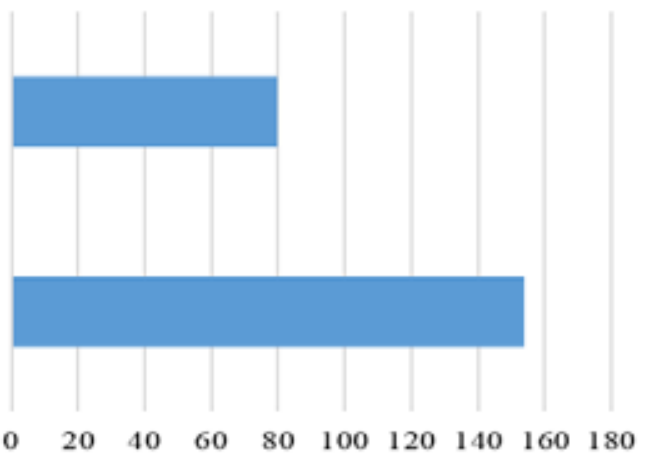

Рис. 14. Досвід проведення відеозапису своїх доповідей, презентацій до початку навчання на пілотному дистанційному курсі «Основи методології розробки електронних курсів у сфері медичної освіти»

Відсутність зацікавленості у впровадженні інформаційно-освітніх технологій в навчальний процес

Мінімальна зацікавленість у впровадженні інформаційно-освітніх технологій в навчальний процес

Нейтральна зацікавленість у впровадженні інформаційно-освітніх технологій в навчальний процес

Середня зацікавленість у впровадженні інформаційно-освітніх технологій в навчальний процес

Максимальна зацікавленість у впровадженні інформаційно-освітніх технологій в навчальний процес

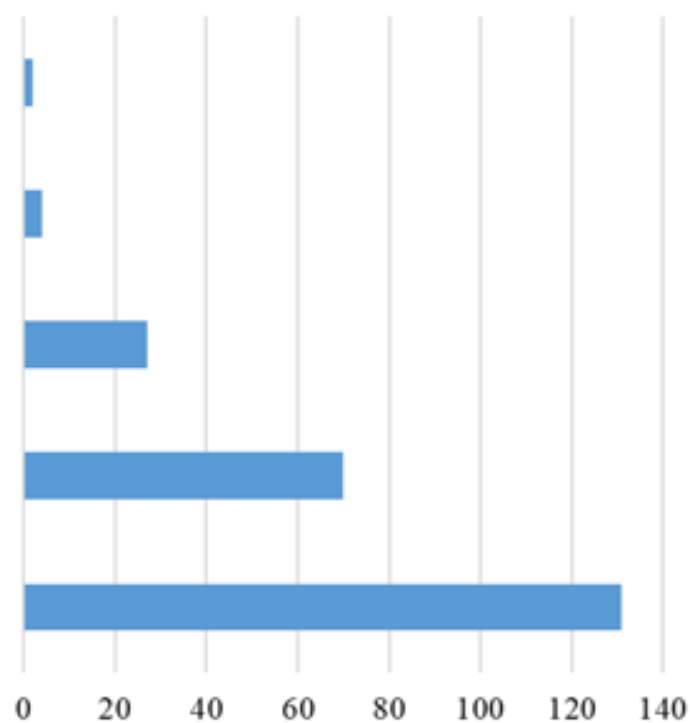

Рис. 15. Оцінка зацікавленості викладачів у впровадженні інформаційно-освітніх технологій у навчальний процес до початку навчання на пілотному дистанційному курсі «Основи методології розробки електронних курсів у сфері медичної освіти» 


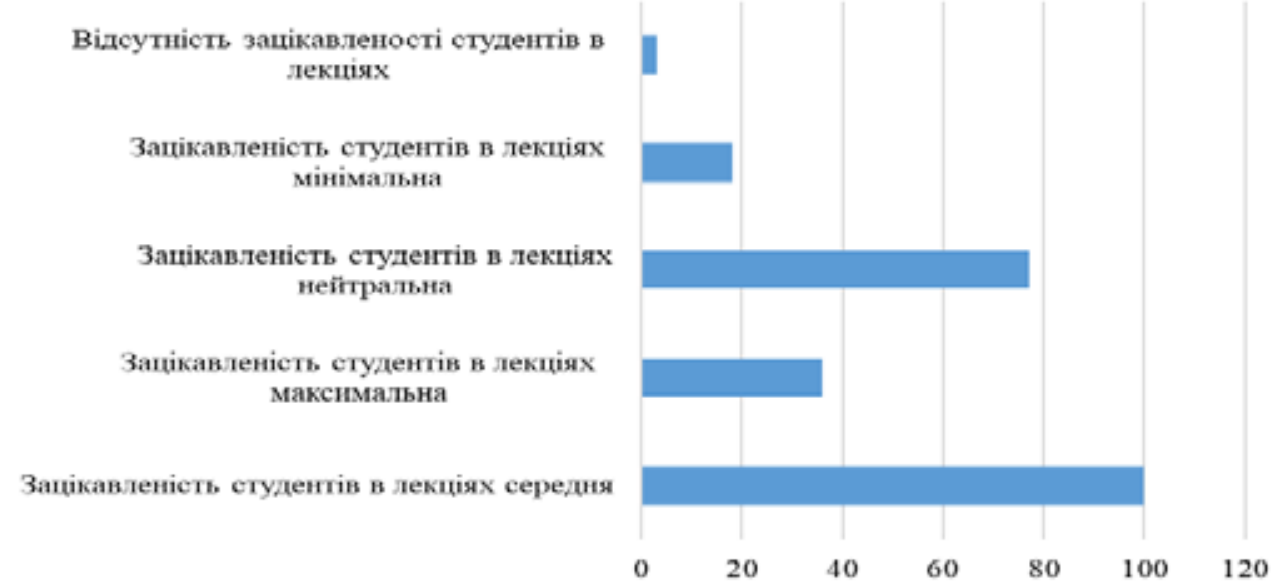

Рис. 16. Оцінка викладачами зацікавленості студентів лекціями до початку навчання на пілотному дистанційному курсі «Основи методології розробки електронних курсів у сорері медичної освіти»

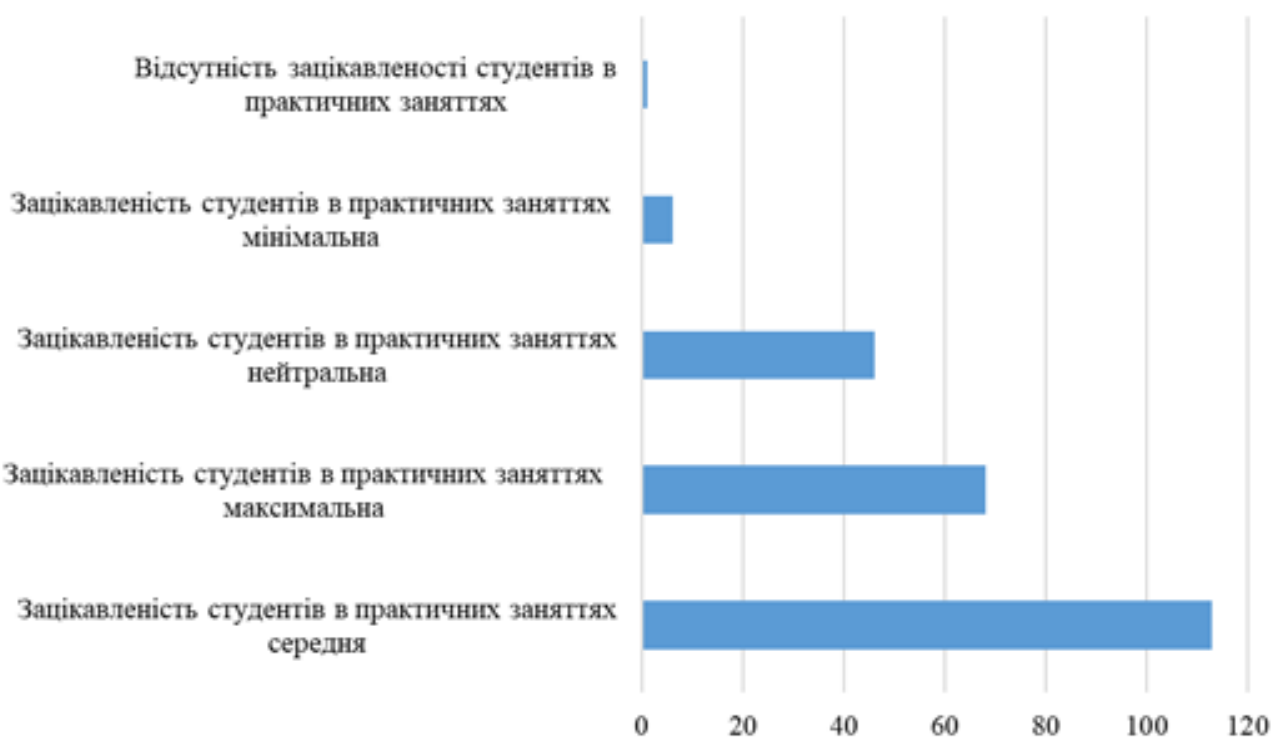

Рис. 17. Оцінка викладачами зацікавленості студентів на практичних заняттях до початку навчання на пілотному дистанційному курсі «Основи методології розробки електронних курсів у сфері медичної освіти»

рівень - 148 (63,25\%), як недостатній - 18 (7,69\%). Троє викладачів взагалі не використовували цю програму в педагогічній роботі (1,28\%) (рис. 7$)$.

Оцінювалися навички викладачів зі створення анімації. Було виявлено, що просту анімацію вміли створювати 113 респондентів (48,29\%), складну 13 (5,56\%), а 108 не використовували в роботі цю технологію (46,15\%) (рис. 8).

Проводилася базова оцінка використання викладачами у своїй педагогічній діяльності автоматизованого тестування. Більшість викладачів ніколи не створювали і не проводили автоматизоване тестування для опитування студен- тів - 139 респондент (59,40\%), 15 використовували автоматизоване тестування щодня (6,41\%), 40 - кілька разів на тиждень $(17,09 \%)$ і 40 - кілька разів на місяць $(17,09 \%)$ (рис. 9).

Досвід проведення вебінарів як спікера базово був у 75 респондентів (32,05\%), 159 викладачів не мали такого досвіду $(67,95 \%)$ (рис. 10).

Більшість викладачів брали участь як слухачі у вебінарах кілька разів на місяць - 155 респонденти (66,24\%), 43 ніколи не брали участі у вебінаpax (18,38\%), 2 - брали участь у вебінарах як слухачі щодня (0,85\%), а 34 - кілька разів на тиждень $(14,53 \%)$ (рис. 11). 
Більшість викладачів ніколи не проходили тренінги підвищення кваліфікації, які б стосувалися дистанційного навчання - 201 (85,90\%), тоді як 33 викладачі мали попередній досвід проходження тренінгів підвищення кваліфікації, що стосуються дистанційного навчання (14,10\%) (рис. 12).

Більшість викладачів не мали попереднього досвіду проведення звукозапису своїх доповідей, презентацій - 154 (65,81\%), 80 респондентів підтвердили наявність попереднього досвіду проведення звукозапису своїх доповідей (34,19\%) (рис. 13).

Більшість викладачів не мали попереднього досвіду проведення відеозапису своїх доповідей, презентацій - 179 (76,50\%), 55 респондентів підтвердили наявність попереднього досвіду проведення відеозапису своїх доповідей, презентацій (23,50\%) (рис. 14).

Більшість викладачів продемонстрували максимальну зацікавленість у впровадженні інформаційно-освітніх технологій у навчальний процес 131 респондент (55,98\%), середню - 70 (29,91\%), нейтральну - 27 (11,54\%), мінімальну - 4 (1,71\%) і два респонденти відзначили відсутність зацікавленості у впровадженні інформаційно-освітніх технологій у навчальний процес $(0,85 \%)$ (рис. 15).

Більшість викладачів оцінили зацікавленість студентів лекціями як середню - 100 респондентів (42,74\%), 36 - як максимальну (15,38\%), 77 - як нейтральну (32,91\%), мінімальну - 18 респондентів (7,69\%), відсутність зацікавленості студентів у лекціях - 3 респонденти $(1,28 \%)$ (рис. 16).

Більшість викладачів оцінили зацікавленість студентів на практичних заняттях як середню 113 респондентів (48,29\%), 68 - як максимальну $(29,06 \%), 46$ - як нейтральну (19,66\%), мінімальну - 6 (2,56\%), відсутність зацікавленості студентів - 1 респондент $(0,43 \%)$ (рис. 17).

Викладачі відзначили такі переваги впровадження в навчальний процес веб-технологій:

- підвищення якості освіти - 135 респондентів $(57,69 \%)$;

- особистісно-орієнтований підхід у навчанні 96 респондентів (41,03\%);

- доступність знань - 155 респондентів $(66,24 \%)$;

- високу технологічність представленого матеріалу - аудіо-, відеоматеріали, сучасні рекомендації з діагностики та лікування - 145 респондентів $(61,97 \%)$;

- можливість навчання без відриву від основної діяльності в асинхронному режимі - 105 респондентів (44,87\%);

- адаптивність (відображення всіх сучасних тенденцій освіти та інформаційного суспільства) 100 респондентів (42,74\%);

- об'єктивізацію й автоматичну систему оцінювання знань студентів - 89 респондентів (38,03\%);
- координування навчального процесу 80 респондентів (34,19\%).

Серед недоліків впровадження в навчальний процес веб-технологій викладачі назвали:

- не бачу недоліків - 22 респонденти $(9,40 \%)$;

- необхідність постійного підвищення кваліфрікації - 13 респондентів (5,56\%);

- необхідність освоєння сучасних освітніх технологій - 34 респондентів (14,53\%);

- значні часові витрати на підготовку якісного освітнього контенту - 127 респондентів (54,27\%);

- необхідність залучення великої кількості персоналу - 21 респонденти (8,97\%);

- $€$ недоліки, проте вони переборні за правильної організації навчально-педагогічної діяльності та більшого залучення студентів - 122 респонденти (52,14\%).

Більшість викладачів зазначили, що читають педагогічну літературу, присвячену сучасним педагогічним технологіям: кілька разів на місяць 132 (56,41\%), 55 - кілька разів на тиждень (23,50\%), 12 - щодня (5,13\%), і 35 викладачів (14,96\%) ніколи не читають педагогічної літератури, присвяченої сучасним педагогічним технологіям.

Більшість також вказали, що можуть кілька разів на тиждень приділяти час на навчання і підвищення кваліфікації відповідно до нових тенденцій в освіті - 128 (54,70\%), 57 (24,36\%) виказали готовність навчатися кілька разів на місяць, 45 щодня (19,23\%), і 4 викладачі зауважили, що не мають часу на проходження курсу підвищення кваліфікації $(1,71 \%)$.

Більшість викладачів ХНМУ відзначили як найважливішу мотиваційну складову частину впровадження інфрормаційно-освітніх технологій у рутинну педагогічну практику: можливість свого професійного розвитку - 117 респондентів (50,00\%), 87 (37,18\%) - підвищення ефрективності в роботі, $30(12,82 \%)$ - полегшення повсякденних завдань.

Також в анкетування-опитування були інтегровані відкриті запитання. Від навчального електронного курсу викладачі-курсанти очікували освоєння методології інтерактивного навчання, новітніх методик створення електронних курсів, набуття нових навичок, оволодіння навичками роботи на платсрормі дистанційного навчання, вдосконалення педагогічних вмінь і навичок, підвищення профресіоналізму та профресійної впевненості, оптимізації процесу навчання, підвищення якості навчання та викладання, отримання зворотного зв'язку від розробника курсу протягом навчання із поясненням помилок із можливістю особистого спілкування, підвищення зацікавленості студентів лекціями та матеріалами практичних занять, сприяння використанню новітніх методів навчання студентів серед працівників кафедри, ознайомлення з основними характеристиками сучасних технологій дистанційного навчання, оволодіння вміннями, 
що стосуються дистанційного навчання, створення курсів, використання електронних курсів у повсякденній практиці, ознайомлення 3 методологією максимального залучення студентів у навчання, методологією проведення занять у дистанційному форматі, методологією підготовки презентацій, за допомогою платформи дистанційного навчання покращення комунікації між усіма учасниками навчального процесу задля реалізації особистоорієнтованого підходу до навчання й оцінювання кожного студента, сучасні принципи та підходи в формуванні якісного освітнього контенту, створення навчальних відео, забезпечення підвищення якості підвищення кваліфікації лікарів, подолання психологічного бар'єру при роботі з новітніми технологіями, оптимізації навчального процесу.

Висновки. Відповідно до проведеного анкетування зроблені висновки про недостатнє базове використання інформаційно-освітніх технологій у рутинній педагогічній роботі, низький базовий рівень попереднього досвіду роботи на будь-якій платформі дистанційного навчання як студента та викладача, зумовлений попередньою відсутністю у навчальному закладі платорорми дистанційного навчання, превалюючий середній рівень навичок роботи у PowerPoint, низький рівень проведення автоматизованого тестування до початку, недостатній рівень попереднього досвіду проведення вебінарів як доповідача, відсутність досвіду проходження попередніх тренінгів підвищення кваліфокації, недостатність досвіду проведення відеота звукозапису своїх доповідей, презентацій. 3 огляду на виявлені дані опитування електронний навчальний курс було укомплектовано темами щодо оптимізації роботи викладачів. Проведення тренінгів підвищення кваліфікації для викладачів закладів медичної освіти обґрунтовано підвищенням якості навчального контенту та переходу до створення зручних електронних навчальних матеріалів, а також потребою викладачів у профресійному розвитку.

\section{БІБЛІОГРАФІЧНИЙ СПИСОК:}

1. Авраменко М.О., Фурик О.О., Юрченко І.О., Філатова О.О. Кроки впровадження інноваційних технологій викладання в педіатрії. Актуальні питання діагностики та лікування алергічних і неалергічних захворювань респіраторної системи у дітей із сателітним симпозіумом «Сучасні технології та інновації викладання педіатрії та пульмонології» : матеріали науково-практичної конореренції конференції (Чернівці, 25-26 жовтня 2016 р.). Чернівці, 2016. C. 3-5.

2. Вороненко Ю.В., Мінцер О.П., Краснов В.В. Організація безперервного професійного розвитку викладачів у системі медичної освіти (аналітичний огляд та пропозиції). Медична освіта. 2012. № 4. С. 6-17.

3. Гульчій О.П., Хоменко І.М., Захарова Н.М., Зеліковська О.O. Досвід використання SMART- технологій у модернізації післядипломної освіти лікарів профілактичної ланки. Інформаційні технології та засоби навчання. 2018. № 65 (3). С. 236-248.

4. Журавльова Л.В., Лопіна Н.А. Сучасні інформаційно-освітні веб-технології в роботі клінічної кафедри. Формування сучасної концепції викладання природничих дисциплін у медичних освітніх закладах : матеріали VIII Науково-практичної конфреренції, присвяченої 210-й річниці ХНМУ та 60-й річниці кафедри медичної та біоорганічної хімії, Харків, 26-27 травня 2015 р. Харків : ХНМУ, 2015. С. 87-90.

5. Журавльова Л.В., Лопіна Н.А. Використання сучасних інформаційно-освітніх ВЕБ-технологій в додипломній та післядипломній підготовці лікарів у контексті Закону «Про вищу освіту». Реалізація Закону України «Про вищу освіту» у вищій медичній та фрармацевтичній освіті України (3 дистанційним під'єднанням ВМ(Ф)НЗ України за допомогою відеоконореренцзв'язку) : матеріали Всеукраїнської навчально-наукової конференції з міжнародною участю, присвяченої пам'яті ректора чл.-корр. НАМН України, проф. Л.Я. Ковальчука, Тернопіль 21-22 травня 2015 р. Тернопіль : ТДМУ, 2015. C. 531-533.

6. Журавльова Л.В., Лопіна Н.А. Запровадження новітніх методів навчання на рівні післядипломної освіти. Матеріали XLVII навчально-методичної конфреренції «Організація навчального процесу студентів з різними кваліфрікаційними рівнями підготовки в ХНМУ». Харків, 2013. С. 225.

7. Журавлева Л.В., Лопина Н.А. Внедрение элементов дистанционного обучения с применением инновационных веб-технологий в непрерывное медицинское образование. Проблеми та перспективи розвитку науки на початку третього тисячоліття у країнах Європи та Азії : матеріали XII Міжнародної науково-практичної інтернет-конференції, Переяслав-Хмельницький, 30-31 березня 2015 р. Переяслав-Хмельницький, 2015. С. 225-227.

8. Информационно-образовательное пространство в работе клинической кафедры в контексте реализации непрерывного медицинского образования : методические рекомендации / сост.: Л.В. Журавлева, Н.А. Лопина. Харьков : ХНМУ, 2015. 36 с.

9. Лопіна Н.А., Журавльова Л.В. Практико-орієнтований кейс-метод навчання в системі безперервної медичної освіти на основі інформаційних вебтехнологій. Неперервна професійна освіта: теорія і практика. 2018. № 3-4. С. 67-73.

10. Лопіна Н.А., Журавльова Л.В. Програма підвищення кваліфікації педагогів закладів вищої медичної освіти з використання інорормаційно-освітніх вебтехнологій в медичній освіті. Неперервна професійна освіта: теорія і практика. 2019. № 1 (58). С. 60-67.

11. Організація інфрормаційно-освітнього вебсередовища клінічної кафедри вищого навчального закладу медичної освіти : навчально-методичний посібник / упоряд. : Н.А. Лопіна, Л.В. Журавльова. Харків : ХНМУ, 2019. 84 с.

12. Мороз В.М., Гумінський Ю.Й., Полеся Т.Л., Фоміна Л.В., Заїка С.В. Реалізація Європейських стандартів вищої освіти у Вінницькому національному медичному університеті ім. М.І. Пирогова. Медична освіта. 2018. № 2. С. 55-60. 
13. Напалков С.В. О технологическом обновлении подготовки современного педагога. Материалы конференции «Педагогические чтения в ННГУ». Нижний Новгород - Арзамас, 2015. С. 833-837.

14. Рожко М.М., Ерстенюк Г.М., Капечук В.В., Іванців М.О., Луцак С.М., Дзвонковська В.В., Сенчій B.М. Сучасні підходи до фрормування високопрофесійного викладача в Івано-Франківському національному медичному університеті. Медична освіта. 2018. № 2. С. $65-68$.

15. Сапожниченко Л.В., Козлова Ю.В. Актуальні проблеми теоретичної та практичної підготовки студентів-медиків при вивченні циклу «Внутрішня медицина» на 6 курсі. Медична освіта. 2018. № 3. С. 67-69.

16. Соколова І.В. Професіійний розвиток викладачів медичного університету: досвід використання навчальної платсорми MoodleCloud. Неперервна профресійна освіта: теорія і практика. 2018. № 3 (60). C. 29-37.

17. Фурик О.О., Рябоконь О.В., Оніщенко Т.Є., Задирака Д.А. Перспективи впровадження інноваційних технологій в медичну освіту. Актуальні питання вищої медичної та фрармацевтичної освіти: досвід, проблеми, інновації та сучасні технології : матеріали навчально-методичної конореренції (Чернівці, 20 квітня 2016 р.). Чернівці, 2016. С. 477-478.

18. Фурик О.О., Юрченко І.О. Роль тьютора у проблемно-орієнтованому навчанні. Всеукраїнська науково-методична відеоконфреренція «Актуальні питання дистанційної освіти та телемедицини 2016», сателітний науково-методичний семінарнарада «Актуальні проблеми методики викладання інфрормаційних технологій у фрармації» (Запоріжжя, 12-13 жовтня 2016 р). Запоріжжя, 2016. C. 166-167.

19. Lopina N. Internal medicine department of higher educational medical institution web-site organization and structure based on modern educational webtechnologies. The Seventh International Conference on E-Learning and E-Technologies in Education (ICEEE2018). Lodz, 2018. P. 10-19.

20. Lopina N, Zhuravlyova L. The Organization of Information and Educational Web-space of the Clinical Department of the Medical Educational Institution. The Educational Review. USA, 2019. № 3 (5). P. 43-49. http://dx.doi.org/10.26855/er.2019.05.001. 